\title{
3-D NUMERICAL SIMULATION OF FLOW AND CLEAR WATER SCOUR BY INTERACTION BETWEEN BRIDGE PIERS
}

\section{Gamal Abouzeid,} Associate Prof., Civil Eng. Dept., Assiut University, Assiut 71516, Egypt.

\section{Hassan I. Mohamed and}

Lecturer, Civil Eng. Dept., Assiut University, Assiut 71516, Egypt.

\section{Shima M. Ali}

M. Sc. student, Eng. At Ministry of water resources and public work, Egypt.

(Received May 28, 2007 Accepted June 19, 2007)

In this paper, the flow and local scour variation around single pier and by interaction between bridge piers are studied using $3 D$ flow model. The model uses a finite-volume method to solve the non-transient NavierStokes equations for three dimensions on a general non-orthogonal grid. The $k-\varepsilon$ turbulence model is used to solve the Reynolds-stress term. The numerical model solves the sediment continuity equation in conjunction with van-Rijn's bed-load sediment transport formula to simulate the bed evolution. The $3 D$ flow model is verified through experimental study in a non cohesive bed material in an experimental flume. The different causes of local scour around the pier are simulated well, such as bow flow, down flow, horseshoe vortex, pressure variation and lee-wake vortex. It is found from this study that the local scour depth by interaction between bridge piers depends on the Froude number, the longitudinal distance between piers and the ratio of pier diameter to channel bed width. The maximum scour depth for double piers is higher than that for single pier. Furthermore, the effect of pier shape on the scour process is studied and it is found that the maximum scour depth for circular pier is less than that for rectangular one for both single and double piers. The effect of double piers on scour hole depth is diminished at $L / D=7$ for circular piles and at $L / D=15$ for rectangular ones. The results show good agreement between simulation and experimental results. Also, empirical equations are developed for computing the maximum scour depth due to the interaction between bridge piers at rectangular and circular shapes. Moreover, empirical equations are developed for computing the length of scour hole at single circular and rectangular piers respectively.

KEYWORDS: Numerical Modeling, Flow, Local Scour, Double Bridge Piers, $k-\varepsilon$ Turbulence Model. 


\section{NOMENCLATURE}

\begin{tabular}{|c|c|c|c|}
\hline$B$ & channel width & $p_{k}$ & $\begin{array}{l}\text { production of turbulent } \\
\text { kinetic energy }\end{array}$ \\
\hline $\begin{array}{l}c_{\varepsilon 1}, c_{\varepsilon 2}, \\
c_{\mu},\end{array}$ & constants in $k-\varepsilon$ model & $Q$ & discharge $e$ \\
\hline$D$ & pier diameter & $U$ & mean velocity \\
\hline$d_{s}$ & maximum scour depth & $u$ & fluctuating velocity \\
\hline$d_{50}$ & $\begin{array}{l}\text { bed sediment grain size at } \\
50 \% \text { passing }\end{array}$ & $t$ & time \\
\hline$F_{e}$ & Froude number & $x$ & length scale \\
\hline$g$ & acceleration of gravity & $\delta_{i j}$ & Kronecker delta \\
\hline$H$ & water depth & $\varepsilon$ & turbulent dissipation of $k$ \\
\hline$k$ & turbulent kinetic energy & $v_{T}$ & turbulent eddy viscosity \\
\hline$L$ & $\begin{array}{l}\text { spacing between centerlines } \\
\text { of the piers }\end{array}$ & $\rho$ & density of water \\
\hline$p$ & pressure & $\sigma_{k}, \sigma_{\varepsilon}$ & constant in $k-\varepsilon$ model \\
\hline
\end{tabular}

\section{INTRODUCTION}

Local scour of alluvial channel beds around obstructions is a problem of continuing interest. The complex three-dimensional flow and sediment transport around such structures have defied an analytical solution to the problem and there are wide divergences in scour depths estimated through the available empirical and semiempirical methods. The time consuming and expensive nature of experimental research on scouring processes caused by flowing water makes it attractive to develop numerical tools for the prediction of the interaction of the fluid flow and the movable bed. The rapidly decreasing computer costs make this approach increasingly attractive.

In the previous the researches on scour are mainly focused on the constructed single bridges. Nowdays the long extended masonry piers are replaced with multiple small reinforced concrete piers. In these cases, the different scour patterns compared to that in the case of constructing the single pier are observed, Choi and Ahn [1] and Yasser [2].

In recent years, several numerical models have been constructed for simulating 3D flow field and/or bed variations around circular piers. Richardson and Panchang [3] used a 3D transient model to compute the flow field around a pier within a given fixed scour hole. Without modeling sediment transport, they estimated the depth of equilibrium scour simply by means of lagrangian particle-tracking analysis. By incorporating various sediment transport models, a few researchers have developed scouring models with various features. Omitting the transient terms, Olsen and Melaaen [4] computed the scour hole development by solving the 3D Navier-Stokes equations with the $k-\varepsilon$ (turbulent kinetic energy and dissipation rate) model for the Reynolds stresses, and the advection-diffusion equation for sediment transport. Olsen 
and Kjellesvig [5] extended the aforementioned model of Olsen and Melaaen with transient terms. Tseng et al. [6] investigated numerically the 3D turbulent flow field around square and circular piers. The simulated results indicated that the velocity and shear stress around the square pier were significantly higher than those around the circular pier. Yen et al. [7] developed a morphological model consisting of a 3D flow model and a scour model to simulate the bed evolution around a circular pier. The large eddy simulation approach is employed to compute 3D flow velocity and bed shear fields.

According to the aforementioned researches, local scour near bridge piers has been studied extensively by many investigators where emphasis has been placed on the formulation of maximum scour depth equations from laboratory experiments and most papers are based on laboratory data. Numerical simulation of flow and local scour around multiple piers seems to have been paid little attention. This paper presents the findings of numerical and experimental investigations for the flow and local scour due to interaction of multiple circular and rectangular piers for steady flow under condition of clear water scour.

\section{MODEL DESCRIPTION}

The computational fluid dynamics code used for this investigation was developed by Olsen [8]. The model has been applied to a number of engineering situations including flow modelling for estimation of spillway capacity, (Olsen and Kjellosvig [9]), simulation of water and sedimentation in a sand trap, (Olsen and Skoglund [10]), simulation of scour around a cylinder, (Olsen and Kjellesvig [5]), and simulation of flow dynamics in a river with large roughness elements, (Olsen and Stokseth [11]). The code solves the Navier-Stokes equations with a $k-\varepsilon$ turbulence closure model on a three-dimensional non-orthogonal grid. This software employs the Navier-Stokes equations for turbulent flow in a general three-dimensional geometry:

$$
\frac{\partial U_{i}}{\partial t}+\mathrm{U}_{\mathrm{j}} \frac{\partial \mathrm{U}_{\mathrm{i}}}{\partial \mathrm{x}_{\mathrm{j}}}=-\frac{1}{\rho} \frac{\partial}{\partial \mathrm{x}_{\mathrm{j}}}\left(\mathrm{p} \delta_{\mathrm{ij}}+\rho \overline{u_{i} u_{j}}\right)
$$

Where $U_{i}$ is the local velocity; $x_{j}$ is space dimension; $\delta_{i j}$ is Kronecker delta (if $i=j$ then 1, else 0 ); $\rho$ is fluid density; $p$ is pressure; and $\overline{u_{i}}$ is the averaged velocity.

A control-volume approach is used for discretization of the equations. The default mechanism for pressure correction is the SIMPLE method, Patanker [12]. This is used for coupling of all cells except those closest to the surface and allows calculation of a free water surface. For these cells, the continuity of water was used to calculate movement of the water surface. The numerical models and the discretization of the equations are described in more details by Rodi [13], Patanker [12], and Melaaen [14].

The $k-\varepsilon$ model is used to calculate the turbulent shear stress for threedimensional simulations. The eddy-viscosity concept with the $k-\varepsilon$ model is used to model the Reynolds stress term as illustrated in Eq. (2) (where the first term on the right-hand side of the equation forms the diffusive term in the Navier-Stokes equation): 


$$
-\overline{\mathrm{u}_{\mathrm{i}} u_{j}}=v_{T}\left(\frac{\partial U_{\mathrm{i}}}{\partial \mathrm{x}_{\mathrm{j}}}+\frac{\partial U_{\mathrm{j}}}{\partial \mathrm{x}_{\mathrm{i}}}\right)-\frac{2}{3} k \delta_{\mathrm{ij}}
$$

The $k-\varepsilon$ model simulates the eddy-viscosity as:

$$
v_{T}=\mathrm{C}_{\mu} \frac{\mathrm{k}^{2}}{\varepsilon}
$$

Where $k$ is the kinetic energy as defined by;

$$
k=\frac{1}{2} \overline{\mathrm{u}_{\mathrm{i}} u_{j}}
$$

$k$ is modelled as:

$$
\frac{\partial k}{\partial t}+\mathrm{U}_{\mathrm{j}}\left(\frac{\partial k}{\partial x_{j}}\right)=\frac{\partial}{\mathrm{x}_{\mathrm{j}}}\left(\frac{v_{T}}{\sigma_{k}} \frac{\partial k}{\partial x_{j}}\right)+\mathrm{p}_{\mathrm{k}}-\varepsilon
$$

Where $p_{k}$ is given by:

$$
p_{k}=v_{\mathrm{T}} \frac{\partial \mathrm{U}_{\mathrm{i}}}{\partial \mathrm{x}_{\mathrm{j}}}\left(\frac{\partial \mathrm{U}_{\mathrm{j}}}{\partial \mathrm{x}_{\mathrm{i}}}+\frac{\partial \mathrm{U}_{\mathrm{i}}}{\partial \mathrm{x}_{\mathrm{j}}}\right)
$$

and $\varepsilon$ is modelled as

$$
\frac{\partial \varepsilon}{\partial t}+\mathrm{U}_{\mathrm{j}} \frac{\partial \varepsilon}{\partial \mathrm{x}_{\mathrm{j}}}=\frac{\partial}{\partial \mathrm{x}_{\mathrm{j}}}\left(\frac{v_{T}}{\sigma_{\varepsilon}} \frac{\partial \varepsilon}{\partial \mathrm{x}_{\mathrm{j}}}\right)+\mathrm{c}_{\varepsilon 1} \frac{\varepsilon}{k} p_{\mathrm{k}}-\mathrm{c}_{\varepsilon 2} \frac{\varepsilon^{2}}{k}
$$

The equations contain five constants which are implied in the used program as, (Olsen [8]): $\mathrm{c}_{\mu}=0.09 ; \mathrm{c}_{\varepsilon 1}=1.44 ; \mathrm{c}_{\varepsilon 2}=1.92 ; \sigma_{\mathrm{k}}=1.0 ;$ and $\sigma_{\varepsilon}=1.3$.

The influence of rough boundaries on fluid dynamics is modelled through the inclusion of the wall law:

$$
\frac{U}{U_{*}}=\frac{1}{K} \ln \left[\frac{30 \mathrm{z}}{\mathrm{k}_{\mathrm{s}}}\right]
$$

As it is given by Schlicting [15], The variable $\mathrm{k}_{\mathrm{s}}$ equals to the roughness height, $K$ is von Karmen constant, $U$ is the mean velocity, $U_{*}$ is the shear velocity and $\mathrm{z}$ is the height above the bed. Boundary shear stress is calculated as:

$$
\tau=0.3 \rho k
$$

This approach is the one, which used by Olsen and Kjellesvig [9] and Olsen and Skoglund [10] and assume that turbulent kinetic energy is the driver for boundary shear stress. In open cells, turbulent kinetic energy can be advected with the flow and dissipated to adjacent cells. However, energy cannot pass through bed cells and is assumed to be transferred from kinetic energy to a force in the form of boundary shear stress. Using this approach boundary shear stress is principally determined by shear near bed through Eqs. (5) and (6).

\section{Calculation of Sediment Transport:}

Sediment is transported as bed load and suspended load. The suspended load can be calculated with the convection-diffusion equation, 


$$
U_{j} \frac{\partial c}{\partial x_{j}}+w\left(\frac{\partial c}{\partial x_{z}}\right)=\frac{\partial}{\partial x_{j}}\left(\Gamma \frac{\partial c}{\partial x_{j}}\right)
$$

in which $\mathrm{c}=$ sediment concentration and $\mathrm{w}=$ fall velocity of sediment particles. The diffusion coefficient $\Gamma$ was obtained from the $k-\varepsilon$ model:

$$
\Gamma=\frac{v_{\mathrm{T}}}{S_{c}}
$$

The Schmidt number $S_{c}$ is assumed to be unity in this study. Eqn. (10) was discretized with a control volume approach.

The bed load can be simulated with bed load equation. However, the existing bed load equations are developed for one-dimensional uniform flow. For a threedimensional flow situation, van Rijn [16] developed a formula in which the bed load was calculated as a concentration in the elements closest to the bed. The suspended load calculation also needs a formula for the concentration at the bed. If this formula is the same as the formula for simulating the bed load, it is possible to simulate both bed load and suspended load at the same time. Then interaction between bed load and suspended load is also simulated. Van Rijn's [16] formula for bed concentration is given as

$$
c_{\text {bed }}=0.015 \frac{d_{50}}{a} \frac{\mathrm{T}^{1.5}}{D^{* 0.3}}
$$

in which $a=$ a reference level, set to $1.5 \%$ of the water depth.

$$
\begin{aligned}
& \mathrm{T}=\frac{\tau_{0}-\tau_{\text {critical }}}{\tau_{\text {critical }}} \\
& D^{*}=d_{50}\left[\frac{\left(\rho_{s}-\rho_{w}\right) g}{v^{2}}\right]^{1 / 3}
\end{aligned}
$$

Where $\tau_{0}=$ bed shear stress; $\tau_{\text {critical }}=$ critical bed shear stress; $\rho_{w}$ and $\rho_{s}=$ density of water and sediment respectively; $v=$ viscosity of the water, and $g=$ acceleration of gravity.

\section{Grid Construction:}

A structured grid mesh on the x-y-z plane was generated. As shown in Fig. (1), a three dimensional grid mesh with 92 elements in the x-direction, 40 elements in the $y$ direction and 14 elements in the z-direction. An uneven distribution of grid lines in both horizontal and vertical directions was chosen in order to keep the total number of cells in an acceptable range and to get valuable results in the area around the cylinder. The following grid line distributions were chosen: in x-direction: 10 cells with a 0.04 $\mathrm{m}, 5$ cells with a $0.01 \mathrm{~m}, 50$ cells with a $0.005 \mathrm{~m}$ and 26 cells with a $0.05 \mathrm{~m}$ respectively. In y-direction: 10 cells with a $0.01 \mathrm{~m}, 20$ cells with a $0.005 \mathrm{~m}$ and 10 cells with a $0.01 \mathrm{~m}$ respectively. In z-direction: 6 cells with $5 \%$ height of the water depth and 7 cells with $10 \%$ of the water depth. 
The circular pier was generated by specifying its ordinates, and then the grid interpolated using the elliptic grid generation method as shown in Fig. (2). However, the rectangular pier was generated by blocking the area of the pier.

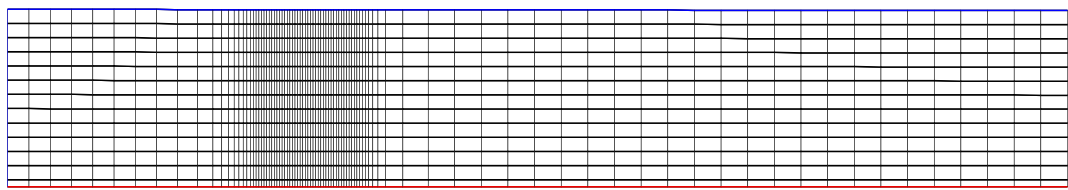

(a) xz-plane for computational grid.

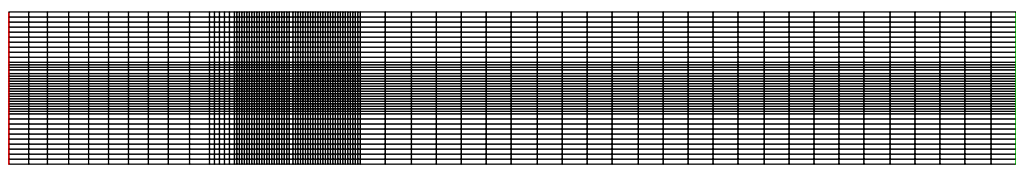

Fig. (1): (b) xy-plane for computational grid.

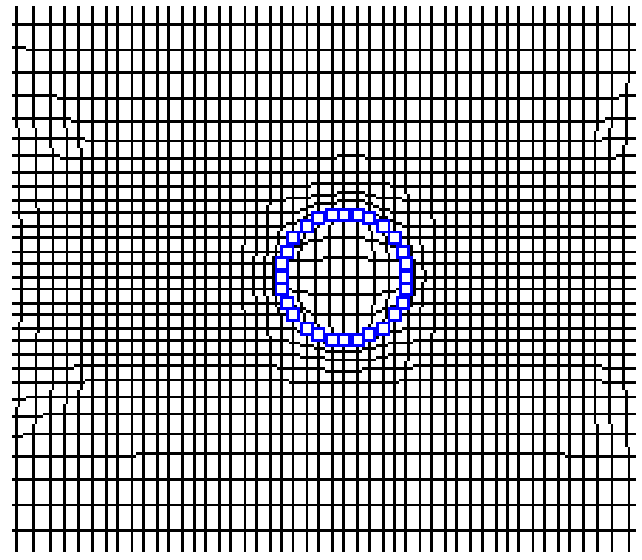

Fig(2): Detailed view of the grid after pier generation.

The only boundary conditions, that were specified, were the water discharge, the geometry and the initial water level, boundary roughness and sediment size. The upstream boundary condition was given by the mean approach flow velocity. Zero gradient boundary conditions at the downstream boundary had to be given to prevent instabilities. This meant that the water discharge at the downstream boundary was not specified.

\section{EXPERIMENTAL WORK}

Particular experiments were conducted in an open rectangular tilting flume with a length of $17.5 \mathrm{~m}$, width of $0.3 \mathrm{~m}$ and depth of $0.5 \mathrm{~m}$ to verify the numerical results. Experiments were carried out under the condition of clear water scour. Table (1) shows the range of variables used in the experiments. Where, three different sizes of wooden piers, 30, 50 and $70 \mathrm{~mm}$ diameter respectively, were used. The flume bed was covered by clean angular sand particles with $\mathrm{d}_{50}=0.9 \mathrm{~mm}$ for a thickness of $20 \mathrm{~cm}$. The flow discharge was changed two times $(8.5$ and $10.5 \mathrm{l} / \mathrm{s})$. Test section located $6 \mathrm{~m}$ away 
from the upstream end. A false floor was constructed along the length of the flume $0.20 \mathrm{~m}$ above the bottom. The experiment was started by carefully filling the flume with water to the required flow depth. This was done with great care so as not to cause too much disturbance to the flow. Two point gauges of $0.1 \mathrm{~mm}$ accuracy were used for measuring water depth in the longitudinal direction and the profile of the scour hole. Each experiment was stopped after a period of 4 hours.

Table (1): Range of variables for laboratory experiments

\begin{tabular}{|c|c|c|c|c|c|}
\hline Parameter & \multirow{2}{*}{ Symbol } & \multirow{2}{*}{ Value } & \multicolumn{2}{|c|}{ Range } & \multirow{2}{*}{ Units } \\
\cline { 3 - 5 } & & & From & To & \\
\hline Pier diameter & $\mathrm{D}$ & $30,50,70$ & 30 & 70 & $\mathrm{~mm}$ \\
\hline Discharge & $\mathrm{Q}$ & $8.5,10.5$ & 8.5 & 10.5 & $\mathrm{~L} / \mathrm{s}$ \\
\hline $\begin{array}{c}\text { Mean water } \\
\text { depth }\end{array}$ & $\mathrm{h}$ & $10.5,12,14,16$ & 10 & 16 & $\mathrm{~cm}$ \\
\hline Froude number & $\mathrm{Fe}$ & varied & 0.134 & 0.172 & - \\
\hline Pier spacing & $\mathrm{L} / \mathrm{D}$ & varied & 0 & 3 & - \\
\hline Sediment size & $\mathrm{d}_{50}$ & 0.9 & - & - & $\mathrm{mm}$ \\
\hline
\end{tabular}

\section{MODEL VERIFICATION}

Series of tests were performed on a single pier and double ones of various spacing and different diameters. Figure (3) shows the experimental values of maximum scour depth as a ratio of mean water depth, $\left(\mathrm{d}_{\mathrm{s}} / \mathrm{h}\right) \exp$, versus the numerical values, $\left(\mathrm{d}_{\mathrm{s}} / \mathrm{h}\right) \mathrm{nu}$, predicted by the 3D numerical model for the different three pier diameters used in this study. It is noticeable the well agreement between the experimental and numerical values of maximum scour depth for both single and double piers. The correlation coefficient between observed and predicted values is 0.92 .

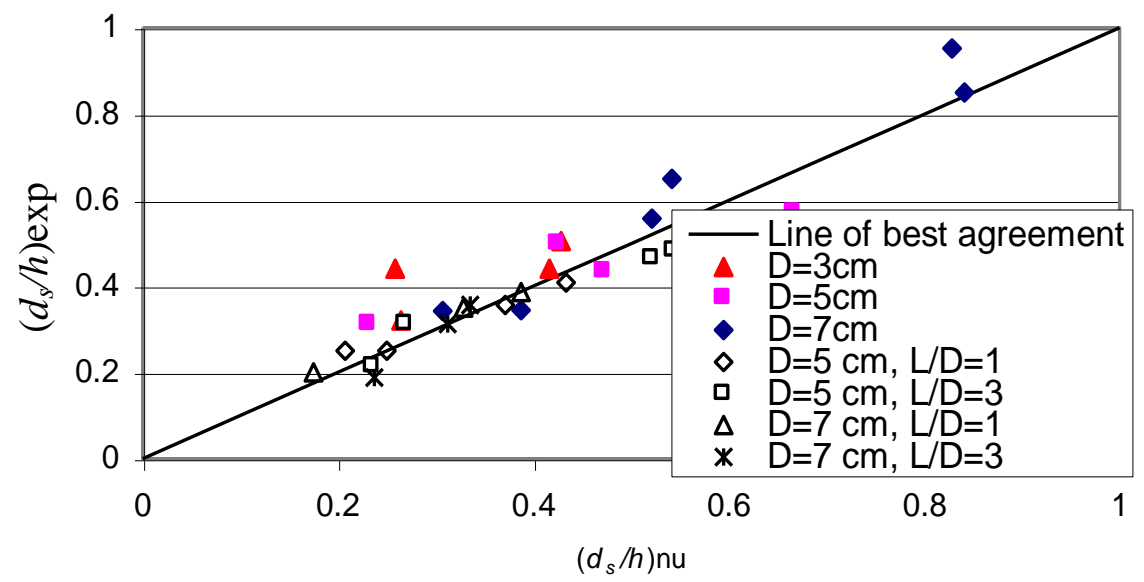

Fig. (3): Experimental values of maximum scour depth versus numerical values for single and double piers at different pier diameters and spacing ratios. 


\section{RESULTS AND DISCUSSIONS}

In the previous section, the numerical model was verified using the experimental data. Now, it is ready to analyze and discuss the numerical results.

\section{Flow patterns and Local Scour around Single Pier:}

Some of the simulated results are plotted in Figs. (from 4 to 8). Since the flow field at far distance downstream is almost the same as that of the upstream inflow, the simulated results are only plotted within the range $-2 \leq x / D \leq 3$ in the $\mathrm{x}$-direction to clearly show the detailed flow field around the pier. Fig. 4 presents the simulated velocity field on the horizontal plane at $\mathrm{z} / \mathrm{h}=0.14$. It clearly shows that reverse flow exists in front of the pier and the horseshoe vortex around the cylinders. Furthermore, the plots clearly show the existence of a separation zone behind the cylinder. The location of the separation point extends further downstream at the surface than close to the bed. The wake region in the numerical model results was defined as the region in which the longitudinal velocities are in opposite direction to the main flow direction and this in agreement with Ali and Karim[17]. In comparison between Figs. (4-a) and (4-b), it obvious that reverse flow becomes stronger by increasing the diameter of the pier.

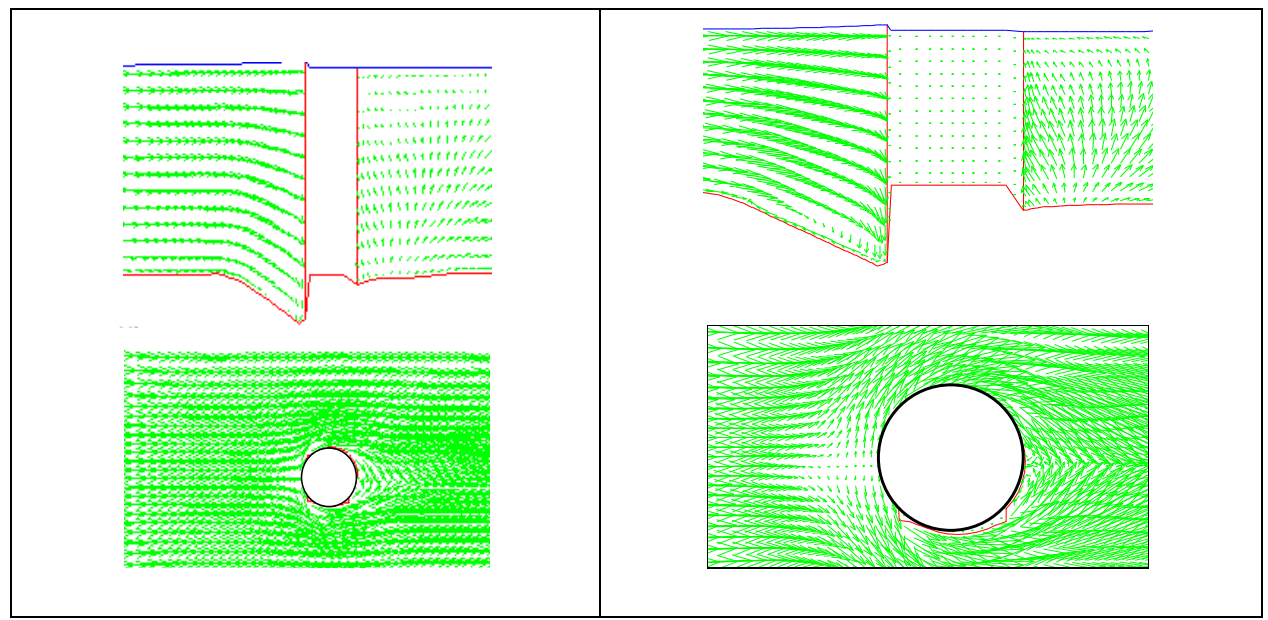

Fig. (4): Velocity vectors for pier diameter $=30$ and $70 \mathrm{~mm}$ respectively at discharge $=8.5 \mathrm{l} / \mathrm{s}$ and approach flow depth $=12 \mathrm{~cm}$.

In Fig. (5), the simulated scour hole bed contours for the flow cases shown in Fig. (4) is drawn. It is noticeable from this figure that, scour hole dimensions depend on the case of the flow around the pier. Furthermore, the scour hole extends around the circular pier with a deeper area at the upstream side and a shallower one downstream and this in well agreement with the experimental observation and previous researches. Also, the scour depth increases with the increasing of the cylinder diameter. 


\section{Flow Patterns and Local Scour Around Double Piers:}

Figure 6 shows a comparison between the velocity vectors around single and double piers respectively at $\mathrm{z} / \mathrm{h}=0.14$. It noticeable the difference in the flow fields between the two cases. In case of double cylinders, the reverse flow downstream the first cylinder hits the second one which make a dissipation for the lee-wake vortex and at the same time activate the horseshoe vortex causing higher local scour depth upstream of the first cylinder.

Figure (7) shows a comparison between the bed profiles at case of single and double piers respectively for the flow cases shown in Fig. (6). It is noticeable the difference between the two, where the scour hole at the double piers is deeper and at the same time the scour depth at the sides of the pier is shallower.

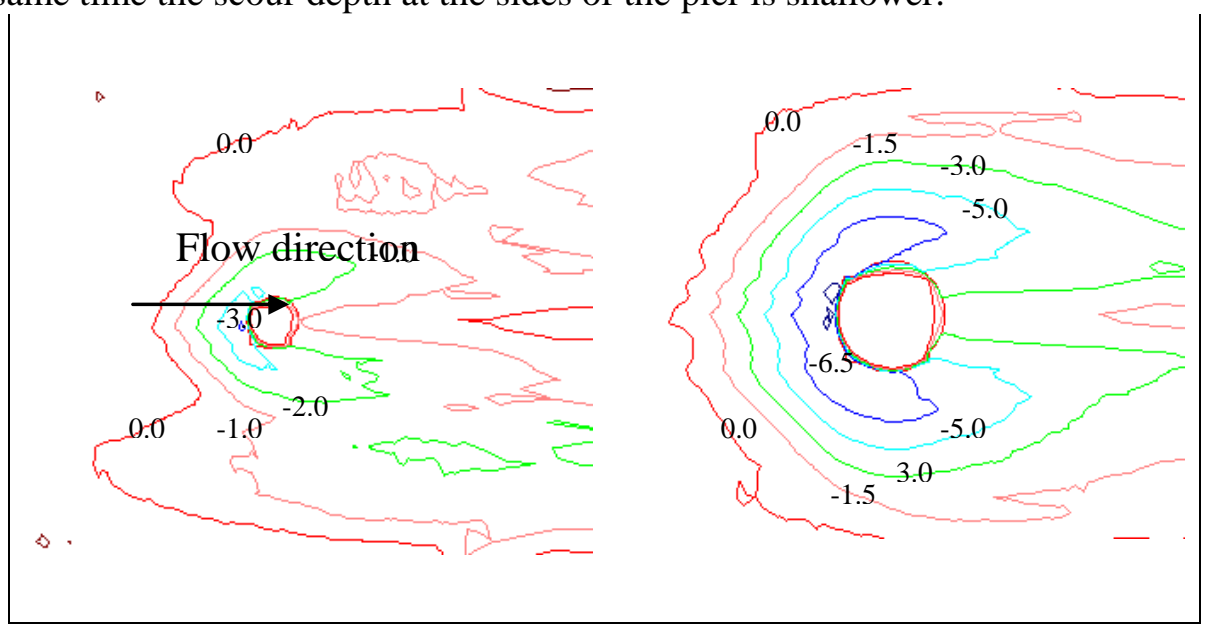

Fig. (5): Simulated final bed elevation contours for pier diameter $=30$ and $70 \mathrm{~mm}$ respectively at discharge $=8.5 \mathrm{l} / \mathrm{s}$ and approach flow depth $=12 \mathrm{~cm}$.

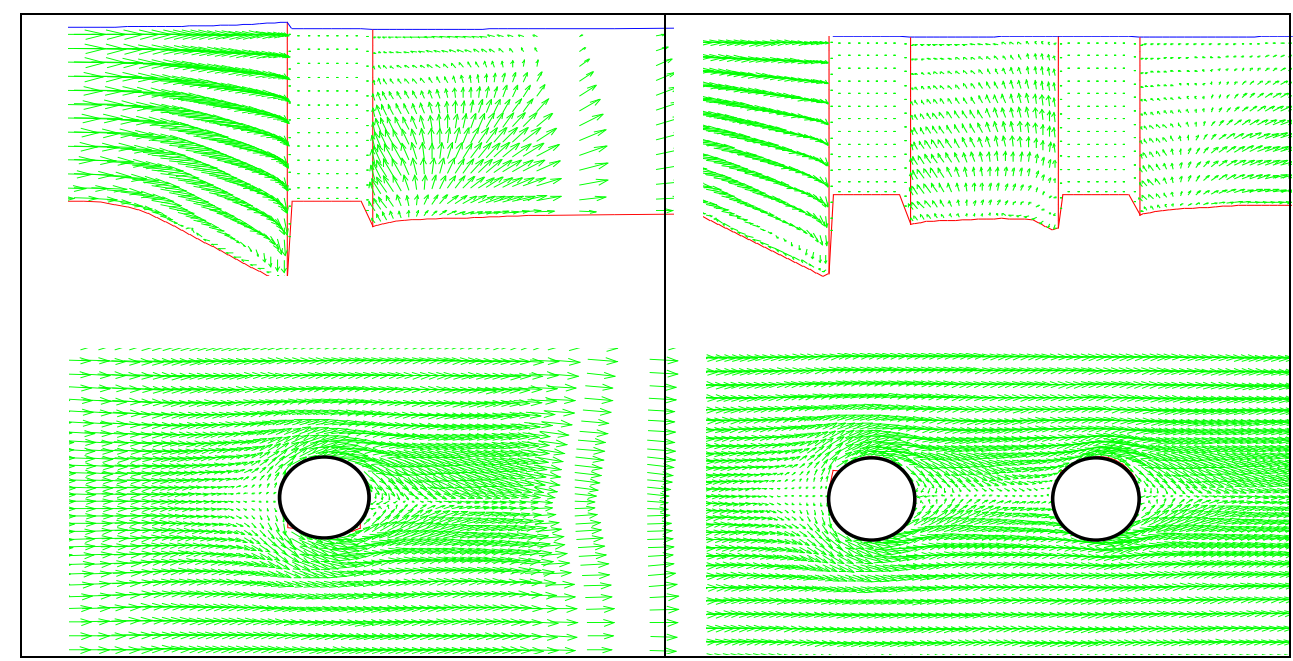

$$
\text { Single pile double pile }
$$

Fig. (6): Velocity vectors for single and double piers $(\mathrm{L} / \mathrm{D}=3)$ at pier diameter $=$ $50 \mathrm{~mm}$, discharge $=10.51 / \mathrm{s}$ and upstream mean water depth $=14 \mathrm{~cm}$. 
Figure (8) shows the effect of the distance between piers on the scour process. It is noticeable that the scour hole area increases by increasing the distance between the piers. Furthermore, the scour depth is greater for $L / D=1$ than that for $L / D=3.0$.

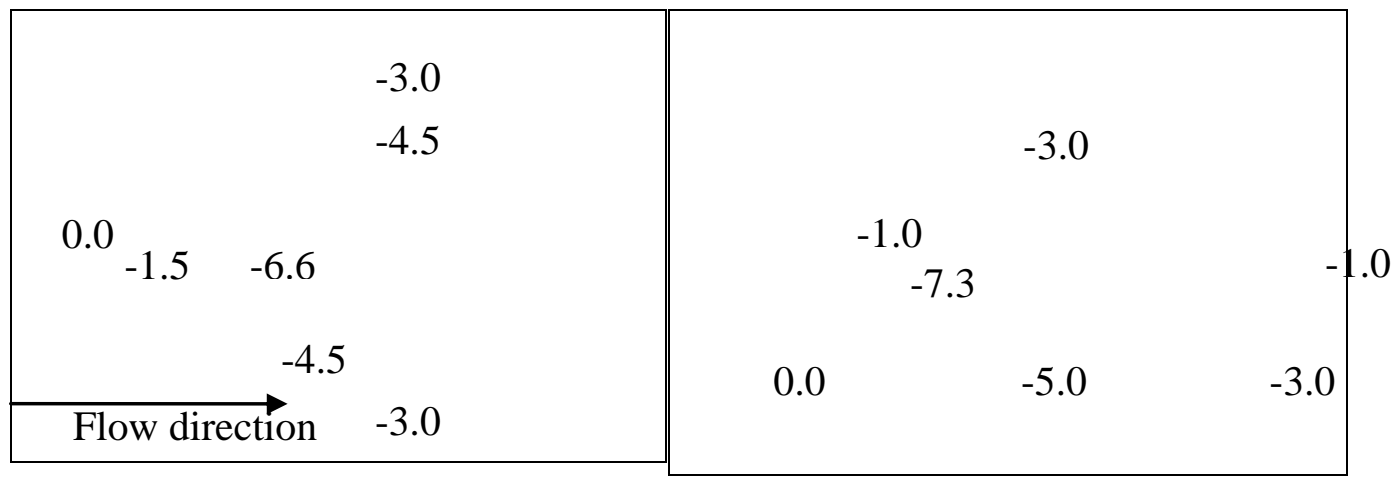

Fig. (7): Bed profiles for single and double piers $(\mathrm{L} / \mathrm{D}=3)$ at pier diameter $=50 \mathrm{~mm}$, discharge $=10.51 / \mathrm{s}$ and mean upstream water depth $=14 \mathrm{~cm}$
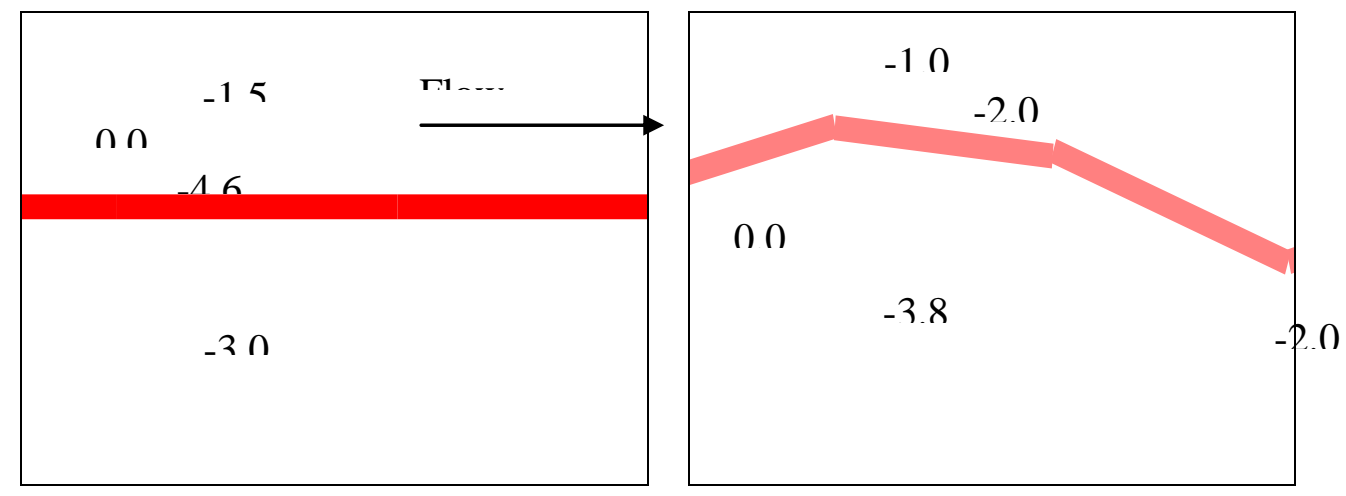

Fig. (8): Bed profiles for $\mathrm{L} / \mathrm{D}=1,3$ respectively at pier diameter $=70 \mathrm{~mm}$, discharge $=$ $8.51 / \mathrm{s}$ and mean water depth $=14 \mathrm{~cm}$

\section{Effect of Pier Shape on the Scour Process:}

Figure (9) illustrates the bed profiles for rectangular and circular piers respectively. From the figure, the dimensions of scour hole for circular pier are less than those for rectangular one. This because the axis of the horseshoe vortex in the front of the circular pier is closer to the pier and weaker than that in the case of rectangular one and also because the velocities of the down flow and reverse flow generated by the circular pier are smaller than those generated by the rectangular one. Figure (10) shows a similar trend for the case of double piers, but with different scour hole dimensions. 


\section{Predicted Equations for Maximum Scour Depth:}

To predict the distance at which each of the double piers works separately, the values of ds/h are plotted against L/D values for different Froude number as shown in Figs. (11 and 12) for circular and rectangular piers, respectively. The figures include the results of single piers. It is shown that the increase of Froude number increases the scour hole depth for both single and double piers at both circular and rectangular ones. Also, it is seen the decrease of scour hole depth with the increase of L/D till L/D reaches to 1 to 2 , then the scour hole increases again with the increase of the distance between the double piers to reach its maximum value. The maximum value of $\mathrm{ds} / \mathrm{h}$ is at $\mathrm{L} / \mathrm{D}=4$ for circular piers while at $\mathrm{L} / \mathrm{D}=8$ for rectangular ones. After these maximum values of ds/h, it decreases with the increase of L/D ratio. The results are extended till the values of $\mathrm{ds} / \mathrm{h}$ for double piers reach the corresponding one for single piers. At this distance, the effect of double piers on scour process is diminished. These distances are at $\mathrm{L} / \mathrm{D}=7$ for circular piers and at $\mathrm{L} / \mathrm{D}=15$ for rectangular piers.

$0.0 \quad-4.0$

$-6.9$
$-2.0$

$-2.0$

\section{0}

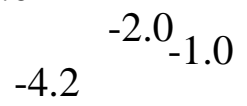

$-1.0$

Fig. (9): Simulated final bed elevation contours for rectangular and circular single bridge piers, respectively $(\mathrm{d}=30 \mathrm{~mm})$ at discharge $=8.5 \mathrm{l} / \mathrm{s}$ and approach flow depth $=12 \mathrm{~cm}$.

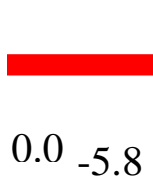

$-2.0$ $-4.0$

5.8
$-4.0$

$-2.0$
$-1.0$

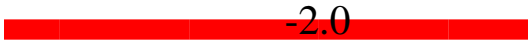

$-3.3$

$-2.0$ $-1.0$

Fig. (10): Simulated final bed elevation contours for rectangular and circular double bridge piers, respectively $(\mathrm{L} / \mathrm{D}=3)$ at discharge $=8.5 \mathrm{l} / \mathrm{s}$ and approach flow depth $=12 \mathrm{~cm}$.

Figures (13 and 14) show the plotting of the maximum values of $\mathrm{ds} / \mathrm{h}$ with $\left(F_{e} \tau_{b} / \tau_{c}\right)$ for different values of $\mathrm{B} / \mathrm{D}$ at circular and rectangular double piers, 
respectively. The relations take straight lines on ordinary scale, where ds/h values increase with the increase of $\left(F_{e} \tau_{b} / \tau_{c}\right)$ while with the decrease of B/D to follow the following equations:

$$
\begin{array}{ll}
\frac{d_{s}}{h}=3.05\left(\frac{\tau_{b} F_{e}}{\tau_{c}}\right)-0.0006\left(\frac{B}{D}\right)^{29} & \text { (For circular piers) } \\
\frac{d_{s}}{h}=1.5\left(\frac{\tau_{b} F_{e}}{\tau_{c}}\right)+\left(\frac{B}{D}\right)^{-0.42} & \text { (For rectangular piers) }
\end{array}
$$

Equations (15 and 16) may be useful for computing the maximum scour depth due to the interaction between bridge piers for both circular and rectangular double piers respectively.

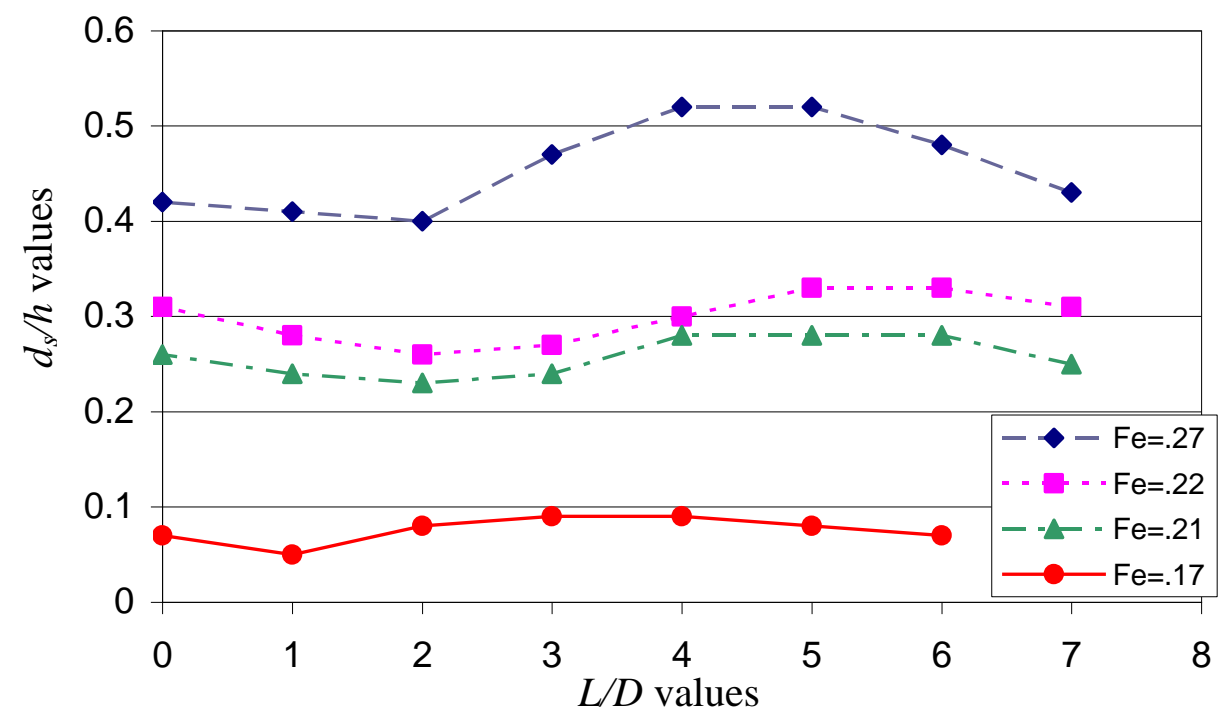

Fig. (11): Variation of $d_{s} / h$ with $L / D$ for different values of $F_{e}$ at $B / D=10$ with circular piles.

Estimation of the longitudinal distance influenced by the interaction between the piers and the flow (length of scour hole, $x$ ) is important for protecting the bed of open channel against scour. So, the value of this distance is predicted and plotted as a ratio of water flow depth $(x / h)$ against Froude number $(F e)$ as shown in Figs. (15 and 16) for both single circular and rectangular piers, respectively. It is seen that the length of scour hole increases with the increase of Froude number and pier diameter for both the circular and rectangular piers. The length of scour hole is larger for rectangular pier the that of circular one. The relationship between $\mathrm{x} / \mathrm{h}$ and $\mathrm{Fe}$ may take the following forms for both circular and rectangular piers respectively:

$$
\begin{aligned}
& x / h=6.35 F_{e}(B / D)^{0.56} \quad \text { (For single circular piers) } \\
& x / h=7.15 F_{e}(B / D)^{0.87} \quad \text { (For single rectangular piers) }
\end{aligned}
$$




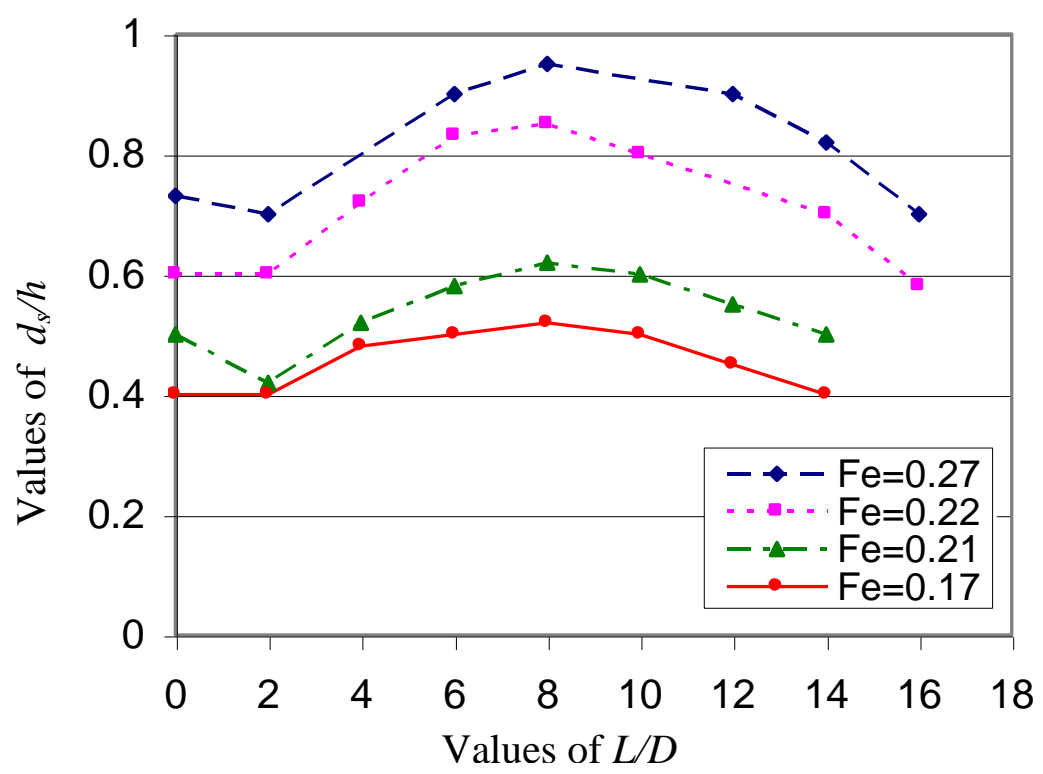

Fig. (12): Variation of $d_{s} / h$ with $L / D$ for different values of $F_{e}$ at $B / D=10$ with rectangular piles.

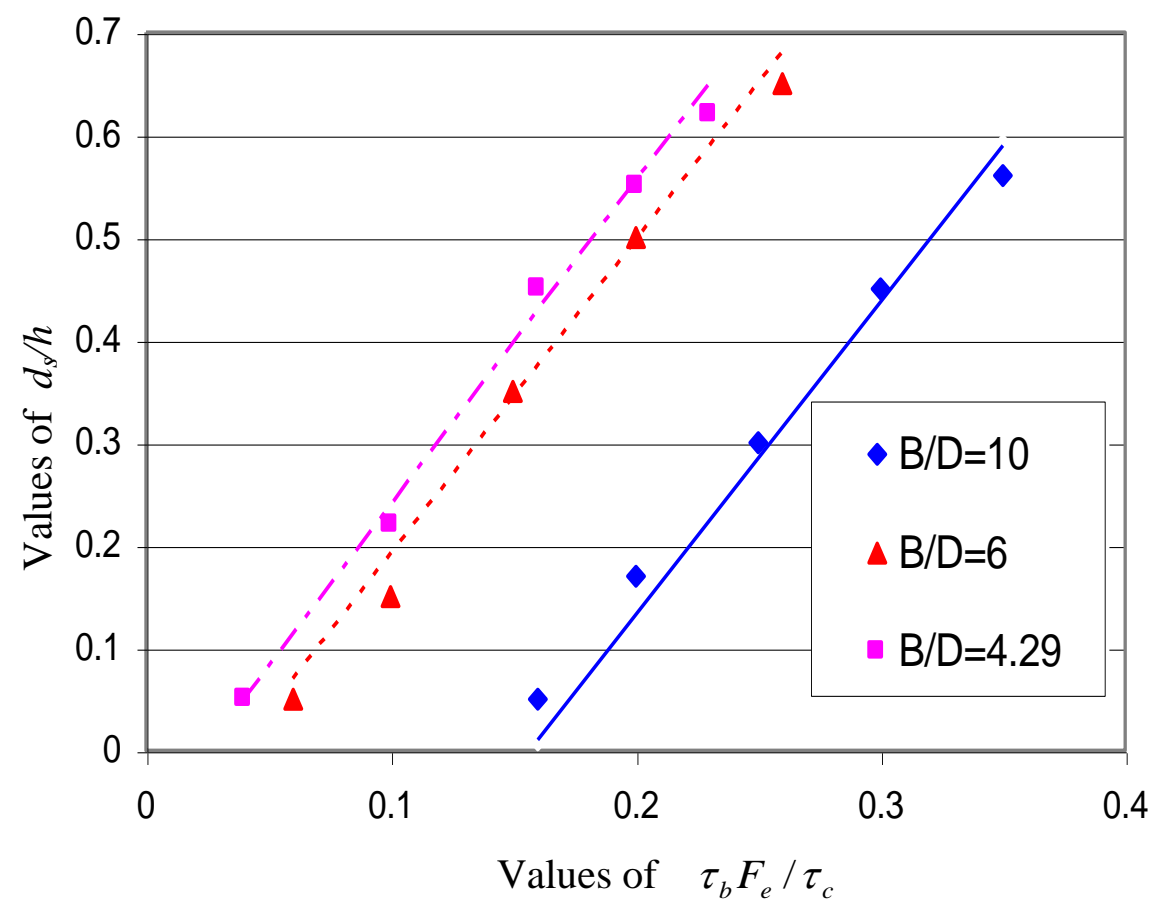

Fig. (13): Variation of $d_{s} / h$ with $\left(\tau_{b} F_{e} / \tau_{c}\right)$ for different values of $B / D$ at $L / D=4$ with double circular piers. 


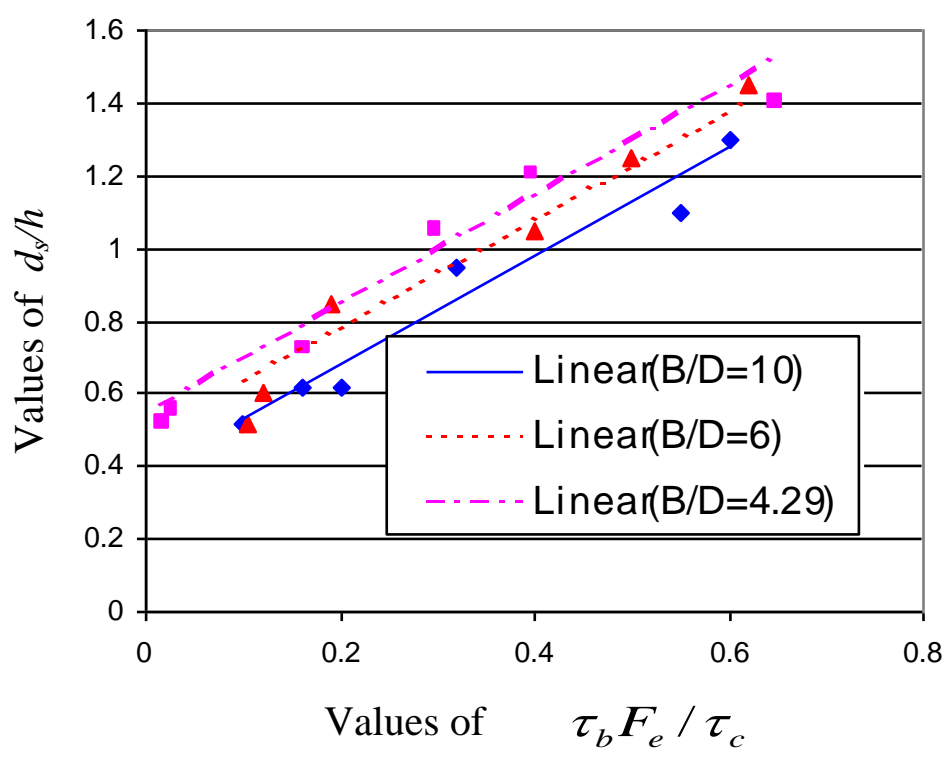

Fig. (14): Variation of $\mathrm{d}_{s} / \mathrm{h}$ with $\left(\tau_{b} F_{e} / \tau_{c}\right)$ for different values of $B / D$ with double rectangular piers at $L / D=8$.

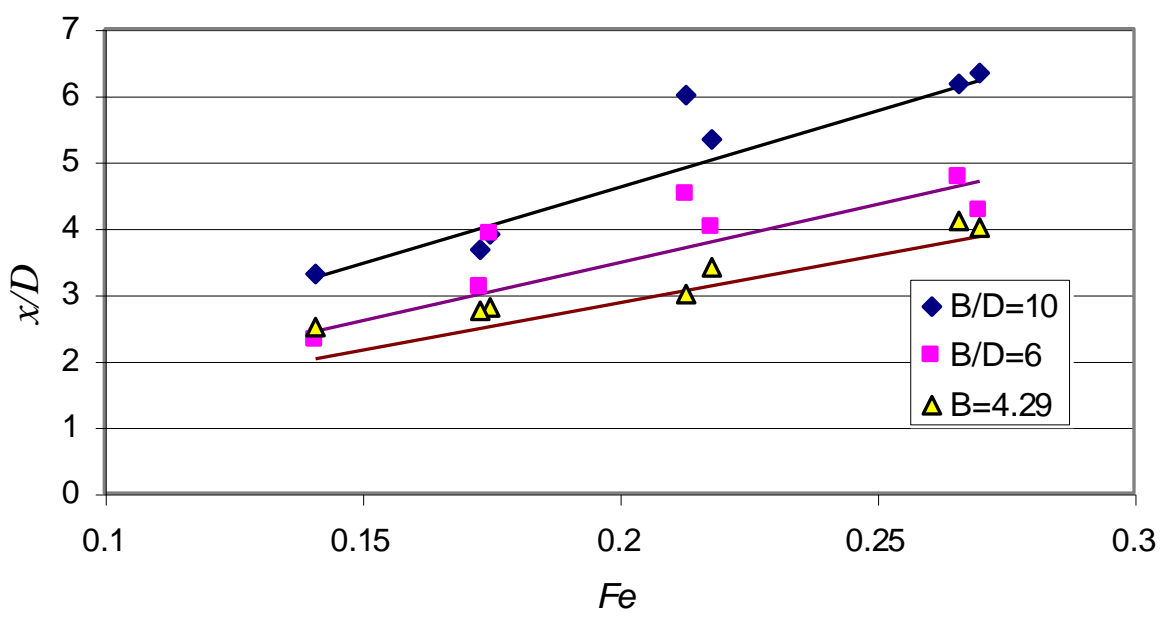

Fig. (15): Variation of $x / D$ with $F e$ for different values of $B / D$ at single circular pier.

\section{CONCLUSIONS}

The main conclusions drawn from this study can be summarized as follows:

1- Flow and local scour around single and double piers have been modeled using 3D numerical model and many parameters which are very difficult to be measured experimentally can be computed using the model, such as the bed shear stress distribution, velocity vectors, afflux upstream the pier. 


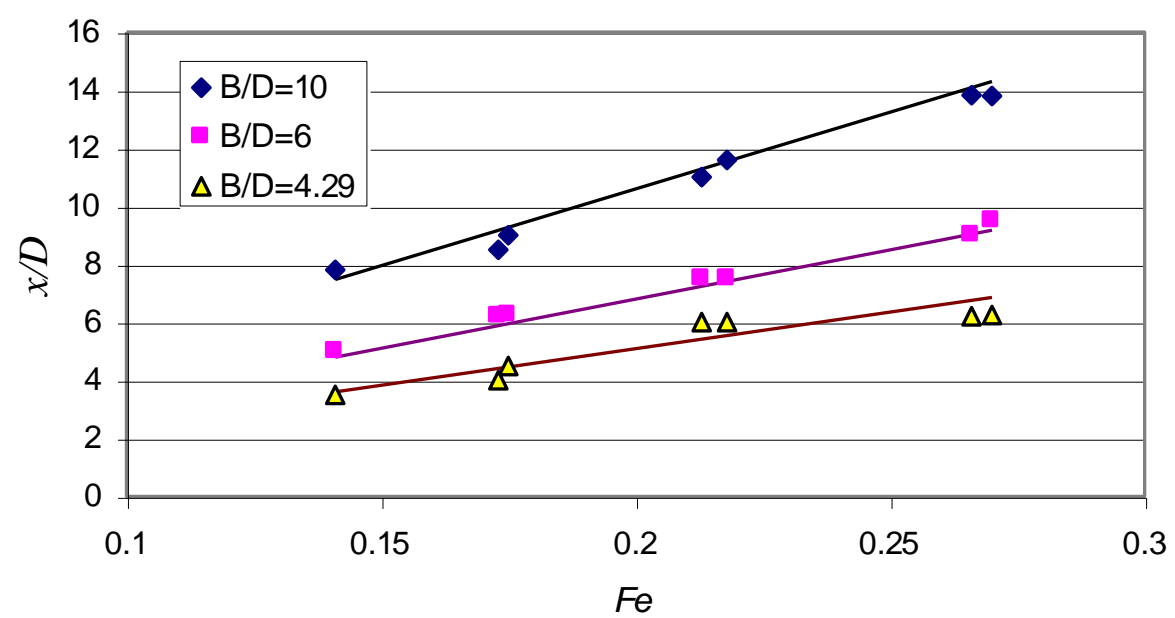

Fig. (16): Variation of $x / D$ with $F e$ for different values of $B / D$ at single rectangular pier.

2- The maximum scour depth at multiple bridge piers is largely affected by the ratio of pier diameter to channel bed width, longitudinal spacing between piers, Froude number and bed sediment size.

3- The maximum scour depth for circular piers is smaller than that of rectangular piers and this in agreement with previous researches.

4- The maximum scour depth increases by increasing the distance between piers and gets a maximum value at $L / D=8$ and $L / D=4$ for rectangular and circular piers respectively then begins to decrease another.

5- The effect of double piers on scour hole depth is diminished at $L / D=7$ for circular piles and at $L / D=15$ for rectangular one.

6- Empirical equations correlating the different parameters have been developed for approximate computation of maximum scour depth and length due to the interaction between bridge piers for both rectangular and circular bridge piers.

\section{REFERENCES}

1. Choi, G. W. and Ahn, S. J. (2001). "Maximum local scour depth variation at pridge piers." IAHR conference, Beijing, China.

2. Yasser, M. R. (1997). "Local scour around bridge piles", M. Sc. Thesis, Assiut University, Assiut, Egypt.

3. Richardson, J. E. and Panchang, V. G. (1998). "Three-dimensional simulation of scour-induced flow at bridge piers." J. of Hydraulic Engineering, ASCE, 124, 530-540.

4. Olsen, N. R. B. and Melaaen, M. C. (1993). "Three-dimensional calculation of scour around cylinders.” J. of Hydraulic Engineering, ASCE, 119, 1048-1054. 
5. Olsen, N. R. B. and Kjellesvig, H. M. (1998). "Three-dimensional numerical flow modeling for estimation of maximum local scour depth." J. of hydraulic Research, IAHR, 36, 579-590.

6. Tseng, M. H., Yen, C. L. and Song (2000). "Computation of three-dimensional flow around square and circular piers." Int. Jour. Numerical Methods in Fluids, 34, 207-227.

7. Yen C. L., Lai, J. S. and Chang, W. Y. (2001). "Modelling of 3D flow and scouring around circular piers." Proc. Natl. Sci. Counc., ROC (A), Vol. 25, No. 1, 17-26.

8. Olsen, N. R. B., (1996), "A three-dimensional numerical model for simulation of sediment movement in water intakes with multi-block option", SSIIM User Manual Version 1.4.

9. Olsen, N. R. B., and Kjellesvig, H. M., (1998a), "Three-dimensional numerical flow modelling for estimation of spillway capacity", Jour. of Hydraulic Research, Vol. 36, No. 5.

10. Olsen, N. R. B., and Skoglund, (1994), "Three-dimensional numerical modelling of water and sediment flow in a sand trap", Jour. of Hydraulic Research, 32, 833844.

11. Olsen, N. R. B., and Stokseth, S., (1995), "Three-dimensional numerical modelling of water flow in a river with large bed roughness." Jour. of Hydraulic Research, 33, 571-581.

12. Patankar, S. V., (1980), "Numerical heat transfer and fluid flow", McGraw-Hill, New York.

13. Rodi, W., (1980), "Turbulence models and their application in hydraulics- a state of the art review", IAHR: Delft.

14. Melaaen, M. C., (1992), "Calculation of fluid flows with staggered and nonstaggered curvilinear non-orthogonal grids-the theory", Numerical Heat Transfer, Part B, 21, 1-19.

15. Schlichting, H., (1960), "Boundary layer theory", McGraw-Hill.

16. Van Rijn, L. C. (1987). "Mathematical modeling of morphological processes in the case of suspended sediment transport." Ph.D thesis, Delft Univ. of Tech., Delft, The Netherlands.

17. Ali, K. H. and Karim, O. (2002). "Simulation of flow around piers." Jour. of Hydraulic Research, 40(2), 161-174. 


\section{التمثيل الرياضي ثلاثي الأبعاد للسريان والنحر حول دعامات الكباري والناتج عن التداخل بينها في الاتجاه الطولي للسريان}

يقدم هذا البحث دراسة نظرية باستخدام نموذج رياضي في الثلاث أبعاد لتحليل السريان هيدروليكيا

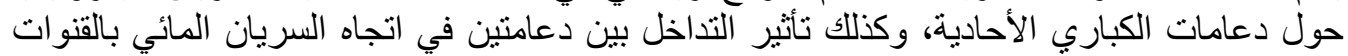

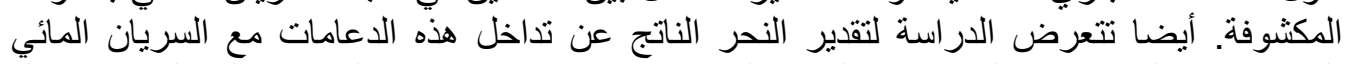

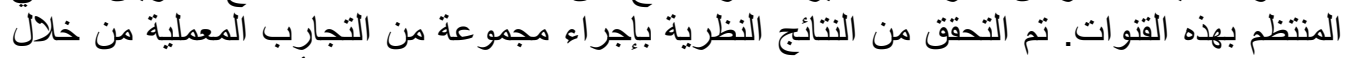

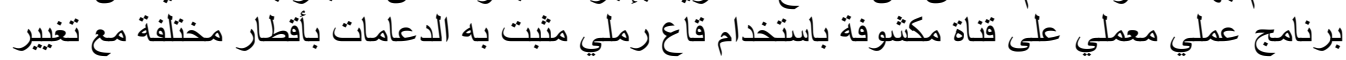
رقم فرويد للسريان بالقناة المكشوفة فئي طريقة الحجوم المحددة (Finite Volume)، إستخدمت في حل معادلات السريان Navier)

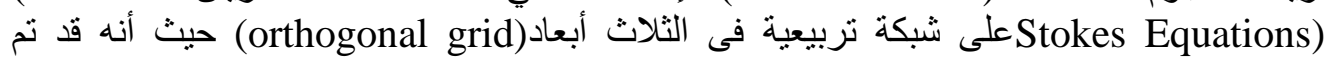

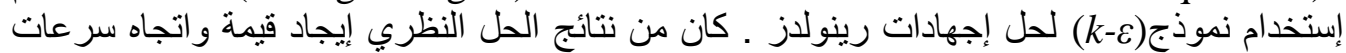

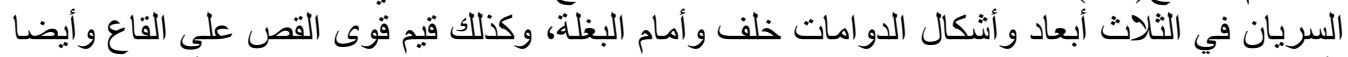

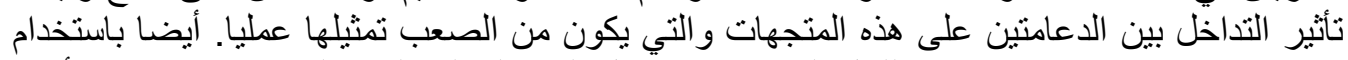

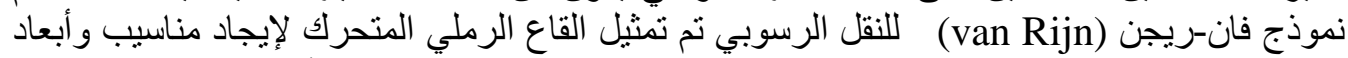

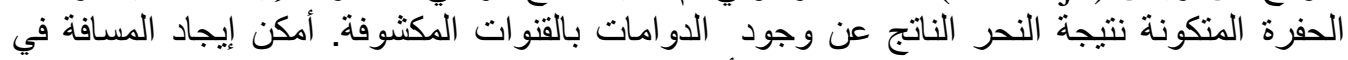

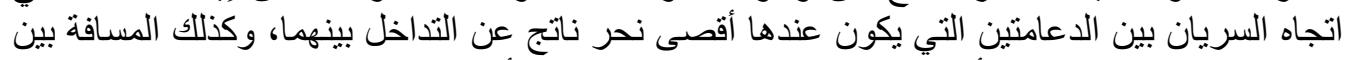

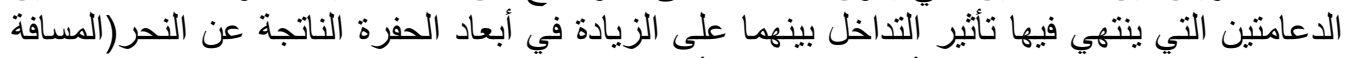

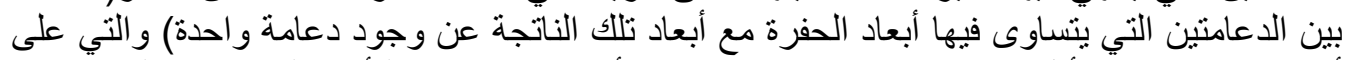

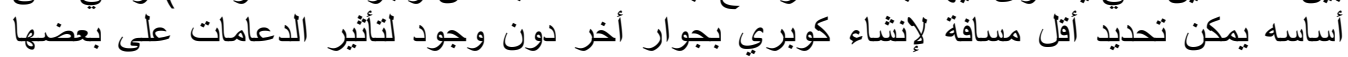

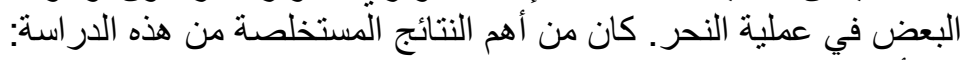

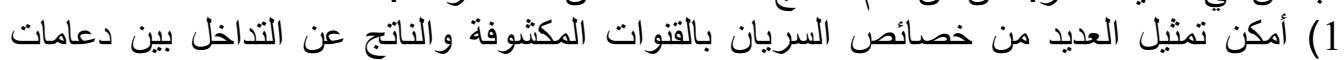

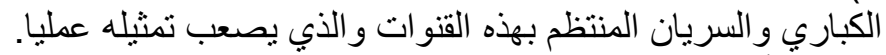

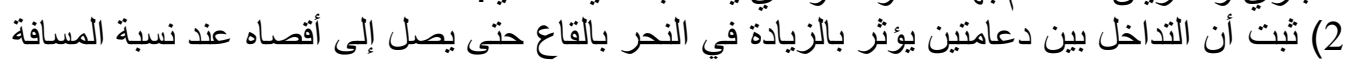

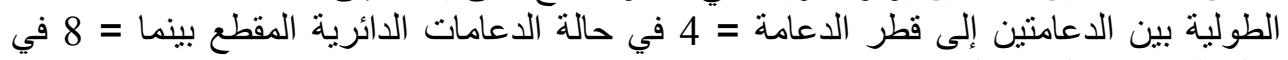
حالة الدعامات المستطيلة.

3) ثبت أيضا أن التداخل بين الدعامتين بنتهي تأثثره على النحر بالقاع عند نسبة المسافة الطولية بين الدعامتين إلى قطر الدعامة = 7 في حالة الدعامات الدائرية المقطع بينما في حالة الداعل الدامات

$$
15 \text { = المستطيلة المعنين }
$$

4) أمكن بالتحليل الرياضي للنتائج استتباط معادلات تجريبية في الصورة الغير بعدية لتقدير عمق وكان

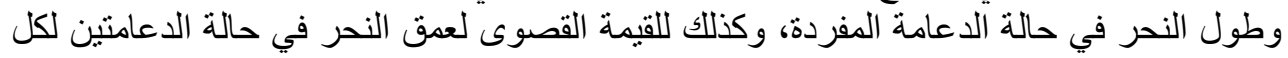
من الدعامة الدائرية و المستطيلة. 